association with African music from the early I920's to the present day. Since 1954 the Library has undertaken its own publications, provided headquarters for the African Music Society, and ' has continually endeavoured to bring to the attention of the musical world the extent and potential genius of African musicians throughout this continent'. A grant from the Ford Foundation in 1960 made possible the publication of an additional hundred disks from material which had already been collected on magnetic tapes in the field. It is important that the initiative and financial backing should be provided for further collection while there is still time, since this 'would add in no uncertain way to the dignity and future cultural status of African peoples everywhere'.

\title{
Radiocarbon Dating of the Nok Culture, Northern Nigeria
}

Mr. Bernard Fagg (Curator, Pitt Rivers Museum, Oxford, formerly Director of Antiquities, Nigeria) reports: An early occupation site was located at Taruga, south-east of Abuja in Niger Province of Northern Nigeria, in November I960, and fourteen exploratory trenches were dug early in January 1961. Figurines characteristic of the Nok style had been found by tin-miners in sample pits close by, and many other figurine fragments were subsequently excavated in situ together with decorated pottery, querns, quartz hammerstones, iron slag, and quantities of charcoal. Charcoal excavated from the third of the four or five layers extending to a depth of about 4 feet, and submitted for determination to Isotopes Incorporated of Westwood, New Jersey, has yielded a dating of $2230 \pm 120$ B.P.

A date of 280 B.C. for an undisturbed Nok site containing abundant evidence of ironworking correlates satisfactorily with the original pre-radiocarbon date for the Nok Culture (based on geomorphological evidence) of the last four centuries B.c. The only other indisputably undisturbed wood specimen (excavated in a completely fresh condition with the bark still unscratched in the heart of the grey clay beds at Nok) gave a carbon date of A.D. 206士50 years ( $Y$ 474). These two dates provide evidence of the existence of a single early Iron Age Culture over nearly five centuries and there is at present no reason to believe that it did not begin earlier and survive later.

\section{The Ogoja Project, Eastern Nigeria}

A PROJECT for comparative linguistic and ethnographic studies in the region corresponding approximately to the Ogoja Province of Eastern Nigeria is being undertaken under the auspices of the Institute of African Studies, Ibadan, and the Committee on Regional Studies of Princeton. The project is being directed by Dr. D. W. Crabb of Princeton University. Work carried out during 1964 included the preparation of a comparative vocabulary of fourteen languages, of a dictionary, and a vernacular primer, together with the collection of two detailed local histories. Six research workers from the Universities of Ibadan, Ghana, and Fourah Bay, together with assistants from the staffs of secondary modern schools in the area, are participating in the project.

\section{The 'Journal of Ethiopian Law'}

THE Journal of Ethiopian Law, the first number of which appeared in the summer of 1964 , is to be published bi-annually by the Faculty of Law of Haile Sellassie I University. It includes cases decided by the Supreme Imperial Court and High Court as well as articles dealing with Ethiopian Law. The subscription per number is $\$ 3.50$ and inquiries should be addressed to: Fred B. Rothman \& Co., 57 Leuning Street, South Hackensack, New Jersey 07606. 